\title{
Including Additional Pollutants into an Integrated Assessment Model for Estimating Nonmarket Benefits from Water Quality $\partial \triangleleft$
}

Robert Griffin Researcher, Natural Capital Project, Stanford University, Stanford, California, and research assistant professor, University of Massachusetts Dartmouth, New Bedford, Massachusetts; rmgriff@stanford.edu

Adrian Vogl Lead scientist, Natural Capital Project, Stanford University, Stanford, California; avogl@stanford.edu

Stacie Wolny Senior GIS analyst, Natural Capital Project, Stanford University, Stanford, California; swolny@stanford.edu

Stefanie Covino Conservation planner, City of Worcester, Planning and Regulatory Services Division, Worcester, Massachusetts; covinos@worcesterma.gov

Eivy Monroy Ecological restoration specialist, Massachusetts Department of Fish and Game, Division of Ecological Restoration, Boston, Massachusetts; eivy.monroy@state.ma.us

Heidi Ricci Assistant director of advocacy, Massachusetts Audubon, Worcester, Massachusetts; hricci@massaudubon.org

Richard Sharp Software architect, Natural Capital Project, Stanford University, Stanford, California; richsharp@stanford.edu

Courtney Schmidt Staff scientist, Narragansett Bay Estuary Program, Providence, Rhode Island; courtney.schmidt@nbep.org

Emi Uchida Professor, Department of Environmental and Natural Resource Economics, University of Rhode Island, Kingston, Rhode Island; euchida@uri.edu

\begin{abstract}
We develop an integrated assessment model for spatially simulating water quality and social welfare from linked ecosystem services that extends prior modeling by incorporating a broader suite of pollutants than conventionally measured factors like phosphorus and nitrogen. Beyond demonstrating the feasibility of such a model, we provide guidance on the impact of omitting or holding constant relevant pollutants and their effect on estimates of water quality and willingness to pay. Applying the model to Narragansett Bay, we find that recent wastewater treatment upgrades and a legacy network of dams are providing millions in annual value to adjacent residents. (JEL Q53, Q57)
\end{abstract}

Land Economics • November 2020 • 96 (4): 457-477 ISSN 0023-7639; E-ISSN 1543-8325

(C) 2020 by the Board of Regents of the University of Wisconsin System

\section{Introduction}

Narragansett Bay is a large estuary in the U.S. Northeast that supports the well-being of more than 2 million adjacent residents through valued uses such as tourism and recreation, commercial and recreational fishing, and more (Figure 1). It is characteristic of many coastal watersheds in the United States that are moving toward compliance with the Clean Water Act by upgrading wastewater treatment practices against a backdrop of changing nonpoint-source pollution drivers. Since 2000, infrastructure upgrades have decreased nitrogen and phosphorus loading by $55 \%$ and $45 \%$, respectively, from wastewater treatment facilities in Narragansett Bay (NBEP 2017). Simultaneously, land use patterns have gradually changed over this same span toward a more urbanized environment: by area, in 2001 the watershed was $33 \%$ urbanized, $57 \%$ forested, and $6 \%$ was devoted to agriculture, by 2011 these figures were $36 \%, 55 \%$, and $5 \%$ respectively (Table 1). Limited monitoring throughout the bay has complicated establishing a net 


\section{Figure 1}

Narragansett Bay Watershed Study Area

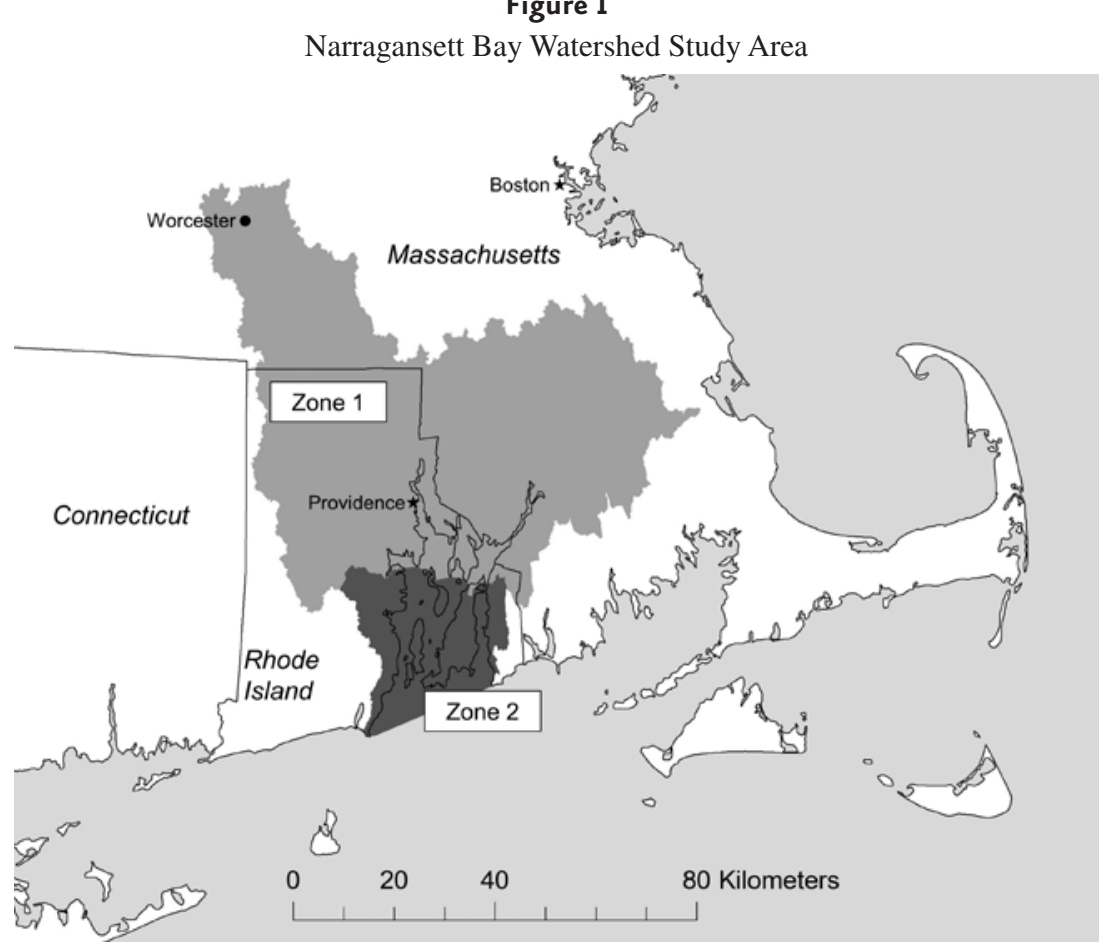

Table 1

Drivers of Point- and Nonpoint-Source Pollution in the Narragansett Bay Watershed

\begin{tabular}{lcccccccc}
\hline & \multicolumn{3}{c}{2001} & & \multicolumn{3}{c}{2011} \\
\cline { 2 - 3 } Variable & Zone 1 & Zone 2 & Overall & & Zone 1 & Zone 2 & Overall \\
\hline Urban land cover (\% of total) & 32.6 & 39.7 & 33.2 & & 35.5 & 41.4 & 36 \\
Forested land cover (\% of total) & 58.5 & 42.8 & 57.2 & & 56.3 & 41.5 & 55.1 \\
Agricultural land cover (\% of total) & 5.6 & 8.1 & 5.8 & & 4.9 & 7.8 & 5.2 \\
Wastewater treatment facilities & 24 & 5 & 29 & 23 & 5 & 28 \\
Onsite water treatment systems & - & - & - & 39,121 & 29,290 & 68,411 \\
Dams & - & - & - & 338 & 14 & 352 \\
\hline
\end{tabular}

Note: Data not available on dams and on-site water treatment systems for 2001.

effect of how these cumulative changes have manifested in water quality attributes or proxies in the bay, such as water clarity and bacterial contamination of swimming areas (NBEP 2017; Oczkowski et al. 2018), though some evidence suggests decreases in total nitrogen (TN), total phosphorus (TP), and chlorophyll $a$, as well as an increase in water clarity (Oviatt et al. 2017).

Given this limited information about the effect of recent changes of key drivers in water quality, stakeholders and decision-makers in this watershed have expressed a desire for a better understanding of the effect of these changes on water quality and human well-being. This is not just a regional consideration: measuring the effect of a given intervention on downstream water quality is complex (Keeler et al. 2012). Modeling frameworks often are poorly integrated between economics and natural sciences and stop short of measuring changes in well-being (Brauman 2015; Polasky et al. 2019), and even those studies that do link water quality interventions to changes in well-being tend to undercount many types of benefits (Keiser, Kling, and 
Figure 2

Model Structure

\begin{tabular}{|c|c|c|c|}
\hline Decision & Ecology & Service & Well-being \\
\hline $\begin{array}{l}\text { Policy and change } \\
\text { Land use } \\
\text { Point source policy } \\
\text { Other regulations }\end{array}$ & $\begin{array}{l}\text { Spatial pollutant flow } \\
\text { Non-point export and } \\
\text { retention } \\
\text { Wastewater loads and } \\
\text { network coverage } \\
\text { Dams } \\
\text { Surface water flow }\end{array}$ & $\begin{array}{l}\text { Water quality index } \\
\text { Multiple pollutants } \\
\text { Mixed modeling } \\
\text { Empirical } \\
\text { Process-based }\end{array}$ & $\begin{array}{l}\text { Benefit transfer } \\
\text { function }\end{array}$ \\
\hline
\end{tabular}

Shapiro 2018). With nearly $\$ 2$ trillion spent on reducing pollution in surface waters in the United States since 1960, there is still considerable uncertainty over the net social welfare implications of water quality improvements from large-scale policies like the Clean Water Act and the Conservation Reserve Program (Keiser, Kling, and Shapiro 2018). While this can partly be attributed to limited spatial and temporal monitoring, and potentially even measurement error in existing U.S. national datasets (Keiser 2018), there is simultaneously a need for improved integrated assessment models (IAMs), especially of the sort that can produce marginal social welfare estimates from common interventions smaller than national programs like the Clean Water Act (Keiser and Muller 2017).

This study develops a spatially explicit IAM that evaluates willingness to pay (WTP) for changes in six dimensions of estuarine water quality that link back to point- and nonpoint-source pollution in the upstream watershed. We use the model to evaluate retrospective and prospective changes in welfare from heuristic and stakeholder-driven policy scenarios in Narragansett Bay. The IAM estimates WTP using a benefit transfer function derived from a meta-analysis regression of stated preference surveys that measure the value of recreational and nonuse values as a function of water quality (Johnston, Besedin, and Stapler 2017). The function employs a water quality index (WQI) as a predictor of WTP that integrates multiple key water pollutants into a single measure on a 0 to 100 scale (Vaughan 1981; EPA 2009). Each pollutant is modeled spatially by characterizing its physical transport and fate as a function of water- shed characteristics and information about nonpoint- and point-source factors, including wastewater treatment facilities, onsite water treatment systems, and more than 350 dams. The IAM structure follows the form of an ecosystem service assessment (Freeman, Herriges and Kling 2014; Olander et al. 2018), using geospatial data and process-based and empirical modeling to provide decision-relevant outputs at each step of the model (Figure 2).

The water quality and economic models employed in this IAM have facilitated a wide array of policy analyses to measure ecosystem service use and nonuse benefits from water quality change (e.g., EPA 2009, 2010, 2015; Meehan et al. 2013; Johnson et al. 2016); however, prior modeling efforts employing these functions have tended to feature only one or two pollutants, usually nitrogen and phosphorus, with limited capacity to simulate spatial and aspatial policy impacts even with this limited set of pollutants under consideration. It is common in the context of IAMs for water quality to be represented by a limited set of water pollutants; in some cases, this is due to the scope of the study being narrowly defined to a subset of effects/uses for which the extra effort to expand the suite of pollutants may be unnecessary. Examples include IAMs that study the use of cost-effective conservation to reduce nitrogen and phosphorus as the primary drivers of hypoxia in the Mississippi Basin (Rabotyagov et al. 2014), sediment impacting coral reef health (Oleson et al. 2017), and climate change impacting water quality through changes in water temperature, dissolved oxygen, nitrogen, and phosphorus (Fant et al. 2017). 
Recent analysis supporting rule making for steam electricity plant discharge in the United States models the effect plant discharge has on nitrogen, phosphorus, sediment, and metals (EPA 2015). The study also incorporated three other pollutants that are thought to contribute to perceived water quality but was unable to model their change due to plant discharge and held them at their sample means. Of these, fecal coliform is unlikely to be affected by steam electrical power discharge and could be left as a sample mean or potentially removed completely from the analysis; however, dissolved oxygen and biochemical oxygen demand are positively correlated with nitrogen and phosphorus through their role in eutrophication, respiration, and decomposition (Heiskary and Markus 2001; Prasad et al. 2011), and leaving these at their sample means may bias results toward higher water quality under increased nitrogen and phosphorus scenarios. While this analysis is generally more inclusive of different dimensions of water quality than prior work, it demonstrates how modeling a limited set of pollutants runs the risk of omitting a pollutant that is directly and/or indirectly affected by a policy or action, with the potential to provide biased estimates of baseline water quality and changes in water quality and social welfare.

We expand prior modeling efforts employing these water quality and WTP functions with a more comprehensive suite of physical models driving six key water pollutants: $\mathrm{TN}$, TP, total suspended sediment, dissolved oxygen, chlorophyll $a$, and pathogenic bacterial contamination. These pollutants are thought be drivers of water quality that impact use patterns (Vaughan 1981; Cude 2001) and vary in their degree of correlation with each other, from uncorrelated to high correlation. As these are also the set of pollutants investigated in recent water quality guidelines by the Environmental Protection Agency (EPA) for polluting entities in the United States (EPA 2009, 2015), using a similar modeling structure while explicitly including these additional pollutants can directly inform policy making. The main scientific contributions of this study are to: (1) investigate the feasibility of including these additional pollutants into an IAM for water quality, and doing so in a spatially explicit manner; and (2) characterize the potential for bias if pollutants are omitted or held constant in scenario analysis.

We explore these by developing and applying the IAM in the context of recent water quality change in Narragansett Bay. The application of the IAM to answer a specific set of questions was motivated by outreach and consultation with stakeholder groups throughout the watershed, following best practices for integrating science in decision-making (Posner, McKenzie, and Ricketts 2016; Ruckelshaus et al. 2015). Through this interaction, several questions emerged as key considerations for decision-making that we explore:

- What was the change in pollutant loading from watersheds flowing into the bay from 2001 to $2011 ?^{1}$ Are specific water quality contaminants more of a problem than others? How has this differed for point- versus nonpoint-source pollution?

- How has recreational use value and nonuse value of Narragansett Bay changed due to changes in water quality?

- What are the well-being impacts of sediment and nitrogen retention by dams and reservoirs?

- Under 2011 conditions, what are natural areas' contribution to well-being based on their influence over water quality in the bay? Where are priority natural areas to conserve for water quality?

\footnotetext{
${ }^{1}$ We use 2001 and 2011 as the change analysis dates; however, the Multi-Resolution Land Characteristics Consortium releases land use data every five years for the United States, so the nonpoint-source pollution estimates we derive from this land use data can be construed as best estimates within a 2.5 year window on either side of their release dates (2001 and 2011). While we attempted wherever possible to use data that align with 2001 and 2011, this lack of annual availability is a characteristic of other data in the analysis as well. As such, it is more accurate to state that we are estimating differences in representative water quality between the five year windows centered on 2001 and 2011. All data used in the analysis are documented in the Appendix.

Periodic improvements in wastewater treatment and nonpoint-source pollution mean there was intermittent change through the decade; however, since we do not have adequate data to account for the timing of changes within the 20012011 period, we have chosen to represent the change as instantaneous as of 2011, where such an interpretation is necessary. In particular, this means that the estimated changes in annual household WTP are for the observed water quality change from 2001 to 2011, going forward from 2011.
} 
The analysis was also strongly influenced by the recently completed report by the Narragansett Bay Estuary Program, The State of Narragansett Bay and Its Watershed (NBEP 2017). In particular, choosing to measure change in water quality from 2001 to 2011 was driven by findings in this report of major decreases in point-source pollution due to wastewater treatment upgrades during this period. Through our modeling efforts here, a key finding is a WTP of \$50 and \$38 (2011 dollars) million per year for these point-source infrastructure upgrades in the upper and lower bay, respectively. Before we answer the remainder of these questions, we turn to the details of the modeling.

\section{Methods}

\section{Valuing Changes in Water Quality}

Water quality enhancements can result in a wide array of benefits that are mediated by environmental factors and the location and use preferences of affected populations (Keeler et al. 2012). The breadth of the services impacted and the requisite modeling and data collection effort to estimate welfare effects from changes in these services has increasingly led researchers to focus on providing generalizable and scalable tools for decision support, with a particular focus on the use of benefit transfer to facilitate analysis (Plummer 2009; Johnston and Thomassin 2010). This approach to valuation uses estimates of WTP for water quality improvements that have been derived elsewhere and applies them at a new study site. It has been tested widely in the context of water quality, and evidence generally supports the use of benefit transfer function approaches when there is no readily comparable site to borrow values from and limited capacity to originate a stated preference survey (Bateman et al. 2011; Rosenberger and Loomis 2000).

The benefit transfer function applied in our IAM, described in detail by Johnston, Besedin, and Stapler 2017, was developed with that purpose in mind, facilitating water quality assessments through a WTP function synthesized from 51 stated preference studies for water quality in the United States. ${ }^{2}$ Derived using a metaregression analysis, the function estimates total (use and nonuse) per household WTP for water quality changes in U.S. water bodies that support ecosystem services including aquatic life, recreational uses (such as fishing, boating, and swimming), and nonuse values, while also capturing variation in site-specific geophysical and demographic attributes (Figure 3). The function is estimated as translog, where the dependent variable (WTP), water quality (baseline and change), and other continuous independent variables are transformed with natural logs to fit nonlinear relationships in the data and ensure that WTP approaches zero as these variables approach zero (Appendix Figure A1).

Producing estimates of WTP from this function requires several steps to ensure consistency with the assumptions of the underlying primary studies. While the Appendix expands on this modeling, several of these steps are worth emphasizing for their implications for the broader IAM. In particular, the primary stated preference studies this function is based on solicited WTP for permanent changes in water quality, typically at an annual time scale; consequently, the models used to measure change in the IAM approximate a long-run equilibrium state of average annual water quality. Spatially, the stated preference surveys asked about discrete water bodies, though an estuary as large as Narragansett Bay has different oceanographic and use characteristics across its range and may be best represented by multiple zones. Similarly, geographic boundaries for impacted populations were a priori imposed in the source WTP studies, leaving the researcher using this WTP function to make a judgment call about the affected market area. ${ }^{3}$ Based on consulta-

\footnotetext{
${ }^{2}$ Other benefit transfer functions are available for use, such as van Houtven, Powers, and Pattanayak's (2007) and Newbold, Simpson, et al.'s (2018). The selected benefit transfer function was chosen due to its use in recent analyses by the EPA.

${ }^{3}$ The metaregression benefit transfer model is not explicitly designed to calculate and sum benefits from joint changes to large (likely) substitute areas of this type (Johnston, Besedin, and Stapler 2017). Guidance in the practice of applying metaregression models is emerging (Kling and Phaneuf 2018; Johnston and Bauer 2019), and newer transfer functions are increasingly capable of dealing with con-
} 


\section{Benefit transfer function}

$W T P_{i}=f\left(W Q, \Delta W Q, G E O, D E M_{i}, \overline{R E S}\right)$
$W T P-$ Willingness to pay/year/household $(i)$
WQ - Water quality index
GEO - Geospatial environmental variables
$D E M-$ Demographic variables/household
RES - Research variables

Water quality index

$W Q=\prod_{i=1}^{6} Q_{i}^{W_{i}} ; \quad 0 \leq W Q \leq 100$

\begin{tabular}{ccc} 
Pollutant $\left(\mathrm{Q}_{\mathrm{i}}\right)$ & Unit & Weight $\left(\mathrm{W}_{\mathrm{i}}\right)$ \\
\hline Dissolved Oxygen & $\# \mathrm{mg} / \mathrm{L}$ & .26 \\
Enterococcus & $\mathrm{cfu} / 100 \mathrm{~mL}$ & .25 \\
Total Nitrogen & $\# \mathrm{mg} / \mathrm{L}$ & .15 \\
Total Phosphorous & $\# \mathrm{mg} / \mathrm{L}$ & .15 \\
Total Suspended Solids & $\# \mathrm{mg} / \mathrm{L}$ & .11 \\
Chorophyll-a & $\# \mu \mathrm{g} / \mathrm{L}$ & .08 \\
\hline
\end{tabular}

Figure 3

Benefit Transfer Model

\begin{tabular}{|c|c|c|}
\hline Variable & $\begin{array}{l}\text { Variable } \\
\text { Type }\end{array}$ & Description \\
\hline Water Quality & WQ & Aggregate water quality index value in focal resource \\
\hline Change in Water Quality & WQ & Change in water quality index value in focal resource \\
\hline Proportion Ag Land & GEO & Ratio of agricultural land in adjacent counties \\
\hline Area Ratio 1 & GEO & Ratio of affected area versus adjacent counties \\
\hline Area Ratio 2 & GEO & Ratio of affected area versus adjacent HUC-10s \\
\hline Relative Size & GEO & Ratio of affected shoreline versus affected area \\
\hline Proportion Change & GEO & Ratio of length of focal resource vs substitutes \\
\hline River/Estuary & GEO & Indicator of river or estuary \\
\hline Region & GEO & Indicators of U.S. geographic region \\
\hline Income & DEM & Median income (2007 US\$) for affected pop \\
\hline Use & DEM & $\begin{array}{l}\text { Indicators for use types considered: fishing, swimming, } \\
\text { boating, non-use value }\end{array}$ \\
\hline Lump Sum & DEM & Indicator of payment format (lump sum or annual) \\
\hline Research variables & RES & $\begin{array}{l}\text { Fixed values associated with research design of sampled } \\
\text { studies used to estimate value transfer function }\end{array}$ \\
\hline
\end{tabular}

tion with local stakeholders and experts in the watershed, we broke the study area into two zones based on their different oceanographic conditions and used the 848,735 households in the Narragansett Bay watershed boundary as the affected market area for each zone. The IAM resolves pollutant movement at scales smaller than the zone level and therefore could be reapplied for any values of market area and spatial zoning of the focal resource. For this study, all water quality calculations and WTP values were calculated based on the overall WQI change induced by an intervention in the respective watershed that corresponds to each of the two zones.

\section{Water Quality Index}

The benefit transfer function uses a WQI to relate multidimensional water quality to WTP. There are more than 50 different water quality indices/indicators developed to track wa-

cerns about double counting with values for multiple water bodies (Newbold, Walsh, et al. 2018; Corona et al. 2020); however, there are theoretical and empirical challenges that remain with these models that lie beyond current guidance. For a review of these issues in the context of practical decision-making on water quality, see Newbold, Simpson, et al. (2018). ter quality (Plummer, de Loë, and Armitage 2012); here we selected an approach based on the Oregon Water Quality Index (Dunnette 1979; Cude 2001) developed by the EPA (EPA 2009). ${ }^{4}$ Variants of this index have been widely used to aggregate disparate water quality attributes into a single index value that can be translated to a public audience qualitatively, typically by demarking thresholds of increasing water quality by use types: safe for boating, fishing, swimming, and drinking (Vaughan 1981; Carson and Mitchell 1993; van Houtven, Powers, and Pattanayak 2007; EPA 2009). The EPA WQI ranges from 0 to 100 , where a value of 25 indicates safe for boating, 45-50 indicates safe for fishing, and 70 indicates safe for swimming. Narragansett Bay is a large estuarine system with biogeochemical properties distinct from freshwater systems; consequently, the WQI index we used was modified by the EPA to include rele-

\footnotetext{
${ }^{4}$ There is a broad array of potential water quality indices that could be substituted into the IAM; we selected this WQI as it has been used previously in the United States for rulemaking by the EPA, is compatible with the benefit transfer function of Johnston, Besedin, and Stapler (2017), and has a degree of scientific support having been developed through expert elicitation and subject to review for consistency (Swamee and Tyagi 2000; Walsh and Wheeler 2012).
} 
vant marine water quality indicators including dissolved oxygen, fecal coliform, chlorophyll $a$, TN, TP, and total suspended solids. We directly substituted enterococcus for fecal coliform concentrations based on updated federal guidance for using enterococcus as the water quality standard for recreational waters.

Translating estimated raw contaminant concentrations to a total WQI value for use in the benefit transfer function and the broader IAM involves several steps. As our IAM is designed to enable spatial scenario prediction and to trace the marginal damage or benefit of changes in water quality back to users and nonusers from spatial interventions such as land use change, we cannot rely completely on observed data and must employ some form of predictive modeling for scenario analysis. Even estimating contaminant concentrations across the entire watershed requires some modeling, as there is insufficient monitoring coverage for all six of the contaminants in the WQI. Therefore, a first step toward calculating a WQI is obtaining data on each of the contaminants in the watershed and evaluating modeling approaches for each. The approach taken to model each pollutant is described in detail below; however, we continue here with the WQI to provide context for modeling choices. The second main step is to convert the concentration estimates for these six pollutants to "subindex" values for each contaminant expressed on a 0 to 100 scale. The subindex transformation curves used are given in the Appendix (Table A1) and are sourced from the EPA (2009). Finally, these subindices are combined to arrive at the final WQI value by using a weighted geometric mean function, shown in Figure 3.5 For our case study of Narragansett Bay, values for the raw concentrations, subindex values, and overall WQI value were calculated by zone for all scenarios, and these WQI values were used as inputs to the WTP benefit transfer function.

This IAM extends prior efforts by spatially modeling a suite of six water pollutants; how-

\footnotetext{
${ }^{5}$ The weighted geometric mean function used for aggregation has been qualitatively shown to have more consistent properties than other aggregation approaches based on first principles (Walsh and Wheeler 2012), though more rigorous testing is warranted to see how it corresponds to actual use patterns. Weights across all pollutants sum to 1 .
}

ever, it is worthwhile to reflect on the nature of this particular WQI function and whether this additional effort is warranted by exploring how the WQI varies if only a subset of pollutants is considered or if some contaminants are held at baseline values:

Omission. In applications using only TN, if $\mathrm{TN}$ is at maximum quality (100) but all other unobserved pollutants are at minimum quality (10), the resulting WQI calculation of 100 would miss that the unobserved pollutants would reduce this to a value of 14 (out of 100). Even in a more favorable setup, where we assume the researcher includes TN and TP and accounts for the relationship these have on dissolved oxygen and chlorophyll $a$ concentrations (as modeled below), setting the known pollutants at max quality and the unknown pollutants (enterococcus and total suspended solids) at minimum quality results in a WQI of 44 versus 100.

Held at baseline. Holding pollutants at baseline levels in a scenario analysis ensures that the baseline water quality will not be biased (unless some pollutants are also omitted). This is important as baseline water quality is a factor in the WTP function. However, doing this will impact the change analysis if factors assumed constant change during the scenario. In a worst case scenario, modeling a change in TN from 10 (minimum) to another value while holding all other factors constant (at minimum levels) could miss up to 90 points of WQI change, depending on how much the other pollutants changed.

This simple exercise demonstrates that there is significant scope for differences in baseline water quality and change depending on the inclusion and measurement of change in pollutants. While we have established bounds on the potential bias, reflecting on this in an applied context as we do here will help characterize the practical extent of this problem.

\section{Modeling Nitrogen, Phosphorus, and Sediment}

For modeling pollutants that link point- and nonpoint-source interventions to water qual- 
ity, we evaluated a wide array of approaches that range on the continuum of mostly process based to mostly statistical in nature. Process-based hydrological models readily allow for spatial analysis and more straightforward interpretation of results due to supporting theory, and are particularly suitable for scenario analysis because they can be used, with appropriate caveats, to evaluate changes outside the range of historical observations (Nearing et al. 1989). However, research on the six contaminants differs widely, and for several of these contaminants there is limited theoretical understanding about the downstream effects of typical management interventions, in particular for pathogenic bacteria. For this IAM, which is oriented toward applied decision-making, we prioritized our selection on process-based models and ease of use, subject to data availability and consistency with the assumptions and form of the WQI and the benefit transfer function. ${ }^{6}$ These considerations resulted in modeling $\mathrm{TN}$, TP, and sediment using the process-oriented InVEST ecosystem services modeling platform (Sharp et al. 2014) and developing reduced-form empirical models for enterococcus, chlorophyll $a$, and dissolved oxygen.

Nitrogen and phosphorus transport modeling for nonpoint-source pollution was done using the InVEST nutrient delivery ratio (NDR) model (Redhead et al. 2018). This model uses a mass-balance approach to hydrologically route nutrients (TN and TP) from diffuse sources, estimating long-term steadystate surface and subsurface nutrient flow to streams. Nutrient sources and retention rates for different land categories are combined with a topographic routing model and a nutrient transport index to estimate the net landscape contribution of nutrients at the watershed outlet. The InVEST sediment delivery ratio (SDR) model was used to produce estimates of sediment transport to catchment outlets on Narragansett Bay (Hamel et al. 2015; Hamel et al. 2017). Similar to the NDR model, the

\footnotetext{
${ }^{6}$ These selection criteria, while informal, contrast to convention in hydrology research where model selection is largely driven by legacy and regional model preferences versus methodological considerations (Addor and Melsen 2019).
}

SDR model calculates net soil loss using land characteristics related to land use and other forcing factors via the revised universal soil loss equation (Renard et al. 1997), as well as a sediment transport index that moves sediment through space based on the hydrological connectivity of the watershed. The SDR and NDR models produce annual estimates of sediment, $\mathrm{TN}$, and TP load at the catchment outlet; no in-stream processes are included in the models. ${ }^{7}$ The advantage of using the spatially distributed SDR and NDR models is that both models produce maps of pixel-level net export at the resolution of the land cover map used in the analysis. As a result, net export can be traced back to particular locations within the watershed and can be aggregated at different potential intervention scales, and land cover maps featuring different nonpoint-source interventions can be compared to estimate spatial differences in pollutant export.

The basic process for parameterizing and calibrating these models was as follows: First, the model for each pollutant (TP, TN, and sediment) was run using a land cover map representing each time period or scenario, land use specific loading and retention factors, climate variables (e.g., precipitation, rainfall erosivity), and soil characteristics. The results are spatially distributed estimates of nonpoint-source pollutant export from the landscape. Next, these estimates were adjusted to account for the retention of sediment and $\mathrm{TN}$ by dams, and then adjusted to account for point-source loadings of TN and TP from wastewater treatment facilities. Sensitivity analyses were then conducted to evaluate model performance, and models were calibrated to watersheds where data were available. Calibrated model parameters were then applied, and the models were rerun for the study area to produce final estimates of loads for these pollutants. More detail is provided in the Appendix.

Several additional steps were necessary to estimate sediment and nutrient concentrations; here we briefly discuss dams, pointsource loading of nutrients, and surface water

\footnotetext{
${ }^{7}$ In-stream processes related to nitrogen and sediment are, however, included in the IAM via the role of dams and reservoirs, as described in the main text and the Appendix.
} 
flow. There are 352 dams in the watershed that have been shown to act as point sinks for nitrogen (Seitzinger et al. 2002; Gold et al. 2016) and sediment (Meade 1982; Renwick et al. 2005). We modeled the retention effect for nitrogen using estimated retention factors (\% of TN load retained annually) derived for all known dams in the watershed, sourced from Gold et al. (2016). As many reaches feature multiple dams, we estimated the cumulative spatial retention factor using a directed graph algorithm, an approach used to address indexing and relating nested watersheds (Leonard, MacEachren, and Madduri 2017). This algorithm spatially delineated the set of upstream watersheds for all dams and accumulated retention while moving down the watershed, providing cumulative retention estimates for all subwatersheds (Yang and $\mathrm{Lu}$ 2014). An analytically identical approach was taken to estimate sediment retention by reservoirs across space, where the retention factor for each dam was calculated using a Brune curve (Brune 1953). These maps were then multiplied by the export maps to create net export maps of TN and sediment and total annual nonpoint loads for each zone in the bay. The effect of dams on phosphorus retention, cycling, and remobilization is complex and site specific, and as a result reservoirs may act as either a source or a sink for phosphorus. While research is progressing on developing approaches for predictive modeling of phosphorus transport through dams, ${ }^{8}$ we opted not to include it in this study.

Annual point-source TN and TP loading from wastewater treatment facilities into each zone in Narragansett Bay was gathered from a recent nutrient budget analysis in the bay (NBEP 2017). Wastewater treatment facilities were grouped by zone, and total load values were calculated by summing across these facilities for each zone and for the relevant analysis years, 2001 and 2011 (Appendix Table A2).

\footnotetext{
${ }^{8}$ Recent research is changing this, and this could soon be a ready addition to the IAM. Maavara et al. (2015) appear to be the first to derive and parameterize a process-based approach for estimating phosphorus retention by dams, using a dataset of 155 dams.
}

The load-based outputs of previous steps were combined with information on flow to estimate mean annual concentrations. River flow into Narragansett Bay is monitored from several main tributaries (NBEP 2017); however, a significant area is ungauged and needed to be estimated to provide full coverage for all tributaries in the watershed. To estimate annual flow volumes for both watershed zones in Narragansett Bay, we used estimates of mean annual runoff volume per land area in the Narragansett Bay watershed (Ries 1990), producing estimates of total annual flow by zone using the respective zone sizes. We then calculated mean annual concentrations for TN, TP, and sediment by dividing their respective total loads (point-source loading from wastewater treatment facilities and nonpoint sources as estimated using the NDR and SDR models) by the flow for each zone. These are representative of the mean annual concentrations of each contaminant entering into each zone from upland and are the values we used in the IAM to calculate water quality in each zone. This freshwater is not explicitly mixed into Narragansett Bay using an oceanographic model and as such becomes less representative of bay water quality farther from shore. 9

\section{Modeling Dissolved Oxygen, Chlorophyll $a$, and Enterococcus}

The other three pollutants were modeled using watershed data and regression models informed by the supporting peer-reviewed literature for each. This work is explained in detail in the Appendix. The main goal was to use these models in a predictive way in the IAM, linking point- and nonpoint-source interventions to changes in the concentration of these contaminants where supported by theory and data. Dissolved oxygen and chlorophyll $a$ concentrations have been found in a wide array of studies to be correlated in estuarine water samples with an array of water attributes, including nitrogen and phosphorus concen-

\footnotetext{
${ }^{9}$ While this was beyond the scope of our study, see Toft et al. (2013) for an example of linking some of the process-based models used in this IAM for a marine water quality model developed for Puget Sound.
} 
trations (Ryther and Dunstan 1971; Hoyer et al. 2002; Prasad et al. 2011; Bbalali et al. 2013; Rai and Rajashekhar 2014). In specifying regression models for these three pollutants there was a practical balance to be made between fit and data availability, where data availability was a two-fold issue: first, was there enough data within sample to include the desired predictors; and second, was there enough data out of sample to extrapolate the regression results to the broader study area? These limitations were a practical concern for modeling dissolved oxygen and chlorophyll $a$. While we were able to estimate more comprehensive models that included other potentially relevant predictors such as water temperature, salinity, $\mathrm{pH}$, and other commonly sampled water attributes, there is limited coverage of these pollutants in the bay and not enough data to support the estimation of mean annual values for each zone. ${ }^{10}$ Because of these data limitations, we limited the predictors to $\mathrm{TN}$ and TP and an interaction term of these to estimate dissolved oxygen and chlorophyll $a$ concentrations (Appendix Tables A13 and A15). It is clear from the range of model specifications that this comes at the cost of model fit. Moreover, this creates a dependency between the models for TN, TP, dissolved oxygen, and chlorophyll $a$, where errors in the TN and TP models will propagate through these other contaminant estimates. However, constructing the model in this way allowed us to estimate the induced effect of interventions that we otherwise would have a difficult time linking in a direct way back to changes in point- and nonpoint-source management.

Enterococcus concentrations were estimated using a regression approach linking key drivers observed in the supporting literature to enterococcus levels observed in Narragansett Bay with a longitudinal dataset from the Rhode Island Department of Health. The peer-reviewed literature investigating the effect of various human uses and watershed characteristics on pathogenic bacterial contamination is dominated by statistical studies with varying conclusions about the effect of drivers like land use, population density, on-

\footnotetext{
${ }^{10} \mathrm{We}$ characterize the potential biases from omitting these relevant variables in the Appendix.
}

site water treatment system (septic system) density, wastewater treatment network coverage, livestock density, rainfall, and more (Fisher et al. 2000; Frenzel and Couvillion 2002; Tong and Chen 2002; Walters, Thebo, and Boehm 2011; Sowah et al. 2014; Sowah et al. 2017; Vitro et al. 2017). We estimated a variety of models using combinations of many of these factors, settling on one with predictors for urban/forest/agricultural land use (\% of the watershed by area), prior 7 day rainfall (inches), wastewater network coverage (\% of watershed by area), and onsite water treatment system density (number of facilities per kilometer ${ }^{2}$ ). We modeled this relationship only for coastal subwatersheds (HUC-12 level) directly adjacent to the bay, in both the estimation and the prediction step, following approaches in the literature and under the assumption that this would provide the best chance to observe significant effects given the weak prior results in other studies.

\section{Results}

What was the change in pollutant loading from watersheds flowing into the bay from 2001 to 2011? Are specific water quality contaminants more of a problem than others? How has this differed for point- versus nonpoint-source pollution?

Recalling that observations alone in the watershed do not provide enough coverage to estimate water quality using the WQI for the years 2001 and 2011, we first present the results of our water quality estimation for both zones using the IAM (Table 2). Water quality conditions in 2001 and 2011 are given as pollutant-specific water quality subindex values (0-100) and raw concentration values (in parentheses). In 2001, sediment, dissolved oxygen, and enterococcus levels were low enough to result in relatively higher water quality subindex values than for the other three contaminants across both zones, with sediment being more of an issue in zone 2 and dissolved oxygen more of an issue in zone 1. Nitrogen and phosphorus concentrations were high enough to drive poor subindex values for 
Table 2

Water Quality Modeling Results for 2001 and 2011

\begin{tabular}{lccccc}
\hline & \multicolumn{2}{c}{2001} & & \multicolumn{2}{c}{2011} \\
\cline { 2 - 3 } \cline { 6 - 6 } Contaminant & Zone 1 & Zone 2 & & Zone 1 & Zone 2 \\
\hline Total nitrogen $(\mathrm{mg} / \mathrm{l})$ & $28(2.8)$ & $47(1.6)$ & & $48(1.6)$ & $58(1.2)$ \\
Total phosphorus $(\mathrm{mg} / \mathrm{l})$ & $38(0.21)$ & $40(0.20)$ & & $58(0.14)$ & $39(0.20)$ \\
Sediment $(\mathrm{mg} / \mathrm{l})$ & $100(17.5)$ & $67(52.6)$ & & $100(19.5)$ & $65(54.2)$ \\
Dissolved oxygen $(\mathrm{mg} / \mathrm{l})$ & $84(7.9)$ & $97(9.7)$ & & $99(10.2)$ & $100(10.3)$ \\
Chlorophyll a $(\mu \mathrm{g} / \mathrm{l})$ & $10(60.9)$ & $19(29.7)$ & & $31(21.0)$ & $36(18.5)$ \\
Enterococcus $(\mathrm{cfu} / 100 \mathrm{ml})$ & $98(40.1)$ & $98(20.3)$ & & $97(64.8)$ & $98(25.4)$ \\
Overall & 57 & 64 & & 75 & 70 \\
\hline
\end{tabular}

those contaminants as well as induce low water quality with respect to chlorophyll $a$, with zone 1 being worse on all values versus zone 2. Overall, water quality in zone 1 was 57 and in zone 2 was 65 , values that fall between a water quality level adequate for fishing and for swimming.

Nearly all subindex values increased between 2001 and 2011 due to lower loads and concentrations, with decreases in TN and TP loading pushing the overall water quality for both zones above the level considered adequate for swimming (EPA 2009). Net loads for TN and TP decreased markedly due to wastewater treatment facility upgrades over the time period (Appendix Table A2), despite slightly higher estimated loads from nonpoint sources of roughly $1 \%$ for both zones and contaminants. Sediment concentration increased by $11 \%$ in zone 1 and $3 \%$ in zone 2 ; however, this trend did not push zone 1 below the threshold for maximum water quality for the sediment subindex $(28 \mathrm{mg} / \mathrm{l})$, but did reduce the sediment subindex in zone 2 . Enterococcus concentrations also increased in both zones in 2011, due to greater rain totals that year and a modest trend toward urbanization, though this had a negligible effect on the subindex water quality value as it had previously been well below the threshold for the maximum possible value $(50 \mathrm{cfu} / 100 \mathrm{ml}){ }^{11}$

\footnotetext{
${ }^{11}$ The maximum possible score for enterococcus is 98 due to the uncertainty of analytical procedures for counting bacteria (Cude 2001). Observed values for onsite wastewater treatment and wastewater treatment facilities remained constant between 2001 and 2011, largely due to data gaps that did not allow us to characterize changes through time. The predicted outputs are driven entirely by the land use categories and prior 7 day rainfall.
}

Chlorophyll $a$ and dissolved oxygen both improved across zones from reduced TN and TP from point sources.

How has recreational use value and nonuse value of Narragansett Bay changed due to changes in water quality?

The overall water quality change between 2001 and 2011 translated to an annual household WTP estimate of $\$ 59.21$ for zone 1 and $\$ 44.58$ for zone 2, or $\$ 50.3$ million and $\$ 37.8$ million, respectively, for the 848,735 households in the Narragansett Bay watershed (Table 3).

What are the well-being impacts of sediment and nitrogen retention by dams and reservoirs?

We estimated the net effect dams play in ongoing sediment and nitrogen retention by conducting a heuristic exercise of removing all dams and comparing that WQI to the existing WQI in 2011 in both zones. We find that dam removal in the watersheds of zone 1 and zone 2 would reduce water quality by 6.3 and 2.5 points in their respective zones in the bay. This change would be nearly entirely due to sediment retention effects, as annual sediment loading increased $271 \%$ in zone 1 and $29 \%$ in zone 2 (TN increases by only $8 \%$ in both zones). A longstanding observed empirical differential between WTP for a water quality gain and willingness to accept payment for an equal water quality loss (Kling, Phaneuf, and Zhao 2012) suggests that the negative WTP estimates here are no better than a first-order estimate of potential lost social welfare and 
Table 3

Willingness to Pay across Scenarios (2011 dollars)

\begin{tabular}{|c|c|c|c|c|c|}
\hline Scenario & Zone & $\begin{array}{c}\text { Baseline Water Quality } \\
\text { (100 point scale })\end{array}$ & $\begin{array}{c}\text { Water Quality } \\
\text { Change (points) }\end{array}$ & $\begin{array}{l}\text { Annual WTP } \\
\text { (\$/household) }\end{array}$ & $\begin{array}{l}\text { Total WTP } \\
\text { (\$M/year) }\end{array}$ \\
\hline \multirow[t]{2}{*}{$2001-2011$} & 1 & 56.5 & 17.9 & 59.21 & 50.3 \\
\hline & 2 & 64.4 & 5.4 & 44.58 & 37.8 \\
\hline \multirow{2}{*}{ Remove all dams (2011) } & 1 & 74.4 & -6.3 & -45.50 & -38.6 \\
\hline & 2 & 69.8 & -2.5 & -36.17 & -30.7 \\
\hline \multicolumn{6}{|c|}{ Alternative WQI Aggregations for 2001-2011 Analysis } \\
\hline \multirow[t]{2}{*}{$W Q=f(T N, T P)$} & 1 & 32.7 & 20.2 & 63.47 & 53.9 \\
\hline & 2 & 43.5 & 4.0 & 41.92 & 35.6 \\
\hline \multirow[t]{2}{*}{$W Q=f(T N, T P, D O, C h A)$} & 1 & 41.3 & 22.6 & 64.47 & 54.7 \\
\hline & 2 & 54.3 & 7.6 & 49.53 & 42.0 \\
\hline \multirow{2}{*}{$W Q=f(T N, T P, S, E)$} & 1 & 59.7 & 14.2 & 55.29 & 46.9 \\
\hline & 2 & 63.6 & 2.3 & 35.05 & 29.7 \\
\hline \multirow[t]{2}{*}{$W Q=f(T N, T P, \overline{D O}, \overline{C h A}, \bar{S}, \bar{E})$} & 1 & 56.5 & 8.9 & 48.48 & 41.2 \\
\hline & 2 & 64.4 & 1.7 & 32.26 & 27.4 \\
\hline \multirow[t]{2}{*}{$W Q=f(T N, T P, D O, C h A, \bar{S}, \bar{E})$} & 1 & 56.5 & 18.2 & 59.47 & 50.5 \\
\hline & 2 & 64.4 & 5.6 & 45.03 & 38.2 \\
\hline
\end{tabular}

Note: WQI, water quality index; WTP, willingness to pay.

highlight a shortcoming of the WTP function used in the IAM in that it cannot currently be used to estimate willingness to accept.

Under 2011 conditions, what are natural areas' contribution to well-being based on their influence over water quality in the bay? Where are priority natural areas to conserve for water quality?

We addressed the question of where to prioritize conservation in the watershed by estimating the change in the WQI (for the appropriate tributary zone) when converting all natural area in a (HUC-12) subwatershed to development and attributing the value of that change back to the natural areas in that subwatershed. ${ }^{12}$ We visualize this using a marginal values map (Ricketts and Lonsdorf 2013), where each subwatershed's value is the marginal contribution of that particular watershed, with all other watersheds held at baseline values (Figure 4). This provides an estimate of the nonpoint-source pollution retention value of natural ecosystems in a wa-

12 "Natural areas" includes the following National Land Cover Database land cover classes: Barren Land, Deciduous/Evergreen/Mixed Forest, Shrub/Scrub, Grassland/ Herbaceous, Woody Wetlands, and Emergent Herbaceous Wetlands. tershed relative to an alternative of developed land, and by holding all else constant we avoid complexities associated with the strong landscape interdependency of hydrological routing (Guswa et al. 2014).

Estimated changes were modest, with a maximum change between -0.99 and 0.43 points on the $0-100$ water quality scale. ${ }^{13}$ This reflects several different important factors within the case study application of the IAM: (1) A significant portion of land adjacent to the bay is already urbanized, with lower potential water quality impact from conversion of natural lands to developed lands, all else equal. (2) Dams play a role in retaining nitrogen and sediment in-stream, leading to lower influence of upstream export or retention by natural lands, all else equal. (3) Transitioning to development from natural areas reduces sediment loading to the bay by trapping sediments from eroding (lowest $\mathrm{C}$ factor of all land classes in the USLE equation used in the sediment model), a process that largely accounts for the increased water quality observed in subwatersheds flowing into zone 2 (where sediment levels are responsible for

\footnotetext{
${ }^{13} \mathrm{We}$ did not monetize these changes, as they are small enough that they are inconsistent with the scale of water quality change that respondents were asked about in the WTP benefit transfer function metadata.
} 
Figure 4

Marginal Water Quality Index (WQI) Change Map for HUC-12 Subwatersheds

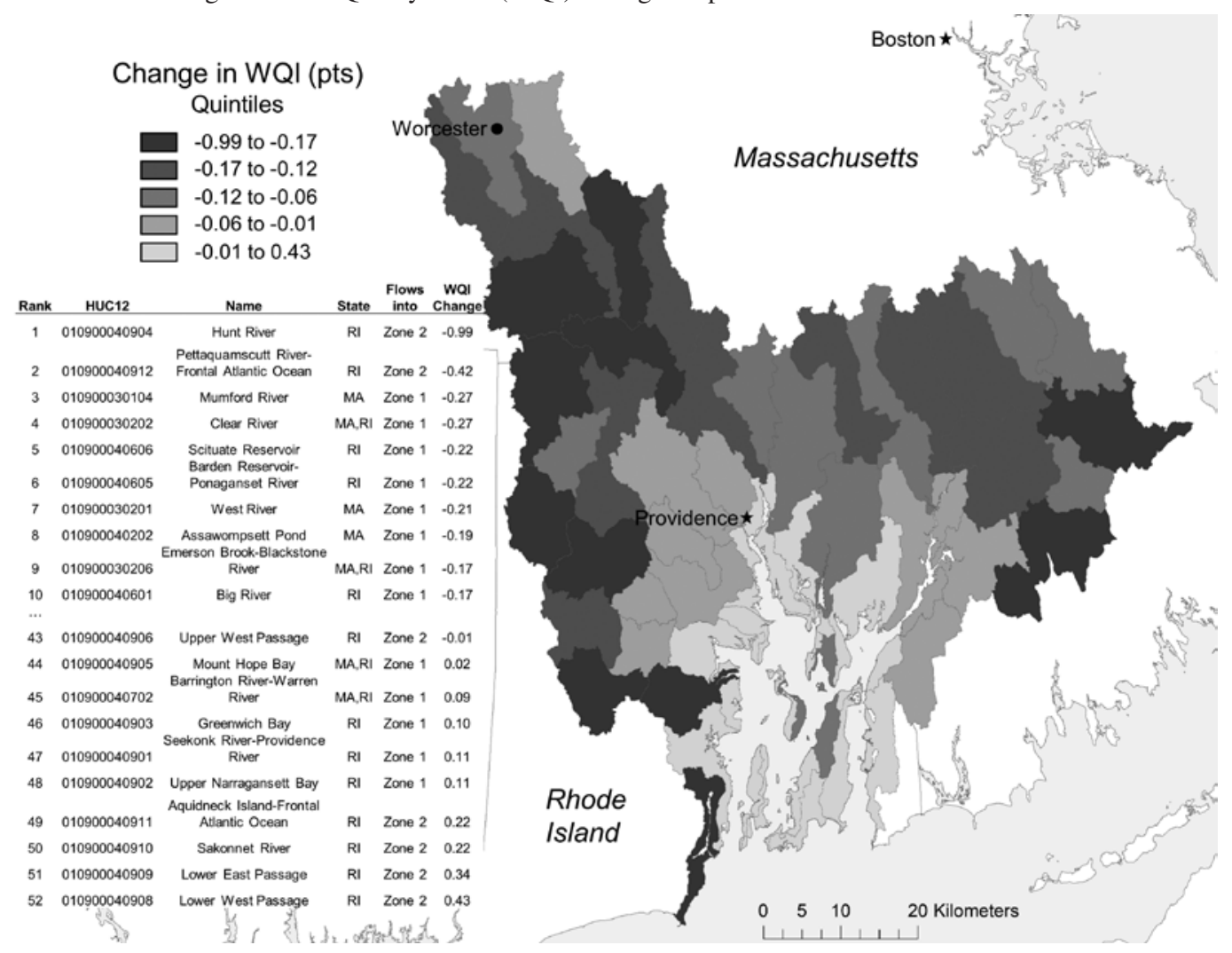

low water quality). (4) These results implicitly capture existing pollution regulations for this region that may mitigate pollution that would occur in the absence of these laws. (5) Several of the pollutant concentrations are below their respective thresholds necessary for a maximum subindex quality score in the 2011 results; therefore, increases in these contaminants from development would change the score only if the increase is large enough to push the contaminant level past the threshold.

\section{WQI and WTP Bias from Alternate Water Quality Estimation Approaches}

As a contribution of this work is to explore the implications of using this WQI and benefit transfer function with contaminants beyond nitrogen and/or phosphorus, we present the results of our retrospective analysis from 2001 to 2011 using five alternative formulations of the WQI (Table 3). The first three omit some of the six pollutants from the WQI and reweight the WQI proportionately (weights still sum to 1) to simulate a study that only went as far as to include these contaminants. The last two include all six pollutants but hold subsets of them constant in the change analysis.

Each of the alternative WQI specifications includes TN and TP, as they are commonly included in water quality assessments, and integrates the correlated (chlorophyll $a$ and dissolved oxygen) and uncorrelated (sediment and enterococcus) pollutants in turn. The main takeaway from the three alternative specifications that omit pollutants is that these produce both biased baseline water quality and biased change estimates versus estimating the WQI with all six pollutants used in this study. Bias in baseline and change esti- 
mates originates from two key factors: (1) as weights vary widely between pollutants, reweighting proportionately cannot make up for lost information from the omitted pollutants; and (2) even when pollutants are correlated, they are not correlated 1:1, and so the relative change across subincides will vary. As baseline water quality and change are both a factor in WTP, these factors bias WTP estimates. ${ }^{14}$ In this case, we observe $+/-$ approximately $\$ 5$ per household per year, depending on which pollutants are omitted.

The two specifications that employ all six pollutants but hold subsets constant in scenario analysis fare better than the omitted pollutant estimates, as the baseline water quality estimates are unbiased. Bias in change estimates depends on the degree of unobserved change in pollutants held at baseline levels. In our case study, holding sediment and enterococcus constant did not meaningfully affect the WQI or WTP, as these pollutants changed only modestly as a result of actions in the watershed from 2001 to 2011. However, if we had not estimated changes in chlorophyll $a$ and dissolved oxygen, our overall change estimates would have been off by greater than $50 \%$ in both zones as compared to the reference WQI that estimates change in all six pollutants.

\section{Conclusions}

Here we report on an IAM that can characterize water quality in a focal resource with incomplete information on contaminants, as well as spatially simulate the effects of common point- and nonpoint-source interventions on water quality. These effects are reported as changes in raw contaminant levels for a suite of six key drivers of water quality, as well as qualitatively on their own and integrated

\footnotetext{
${ }^{14}$ The functional form of the chosen benefit transfer function quickly plateaus as a function of WQI change and is relatively insensitive to a shift in baseline water quality (Appendix Figure A1), so if this particular benefit transfer function is used as part of an IAM for water quality, then WTP estimates may not differ significantly from alternate specifications. For our alternate specifications explored here, the mean absolute value of bias in WQI change was $31 \%$, while the absolute value of bias in WTP was only $11 \%$.
}

together using subindices and an aggregate WQI. The IAM links these water quality metrics to a benefit transfer function to allow for the estimation of recreational use and nonuse WTP values that arise from changes in water quality. We applied this IAM in the context of a watershed experiencing dynamic pointand nonpoint-source changes in pollution over recent years to estimate the change in social welfare attributable to the effect these changes have had on a regionally important downstream resource, Narragansett Bay. This analysis demonstrates that significant regional value has been created mainly as a function of improvements to wastewater treatment facilities since 2001.

Because the IAM is spatially explicit, we were able to investigate the role that existing natural areas play, relative to an alternative development use, in maintaining water quality in Narragansett Bay. We did so by conducting a marginal mapping analysis, evaluating each subwatershed in turn by simulating a land use conversion where all natural areas are replaced by development. While forests, grasslands, and wetlands play a retention role in the transport of nutrients and sediment into adjacent streams (Allan 2004), here we were more accurately measuring the net effect of natural area removal and an alternate development use, each with its own unique export and retention factors, mediated by the retention effect of dams. We find modest marginal WQI impacts from this transition across the watershed: in some areas this is due to an existing high proportion of urban land, in others it is due to cumulative dam retention. Overall this watershed features very little agriculture and fertilization relative to other commonly impaired watersheds with severe downstream impacts, such as the Mississippi River basin (Rabotyagov et al. 2014). While it may be tempting to assume that conservation would have limited impact in these watersheds, it is important to note that there is likely a greater cumulative effect at larger scales than the HUC-12 subwatershed level, though such large-scale interventions are typically beyond the scope of even process-based models. ${ }^{15}$

\footnotetext{
${ }^{15}$ Nonmarginal change tends to break assumptions of water quality models; however, smaller-scale change tends to
} 
We did not evaluate localized water quality effects on freshwater resources that are also extremely valuable in this watershed, such as the Scituate Reservoir, which supplies drinking water to over $60 \%$ of the residents of Rhode Island. We also did not evaluate WTP for drinking water or any of the other ecosystem services provided by natural areas. While most of these are beyond the scope of the IAM, modeling freshwater water quality for recreational and nonuse purposes is an obvious potential extension.

We also took advantage of the IAM's flexibility to investigate an often overlooked, but increasingly important part of addressing a significant legacy of small-scale dams in the United States (Gold et al. 2016). Dams provide an ongoing retention effect over several key drivers of decreased downstream water quality, and while individually the effect of a dam removal is relatively small in our study area, the cumulative effect could be large enough to warrant inclusion in a comprehensive watershed management plan. Valuing this service can provide a fuller accounting of costs when investigating trade-offs against potential benefits of dam removal (Roy et al. 2018). Given the differential effect of sediment and nitrogen in this case study on water quality, a useful next step would be an assessment similar to this one that provides practical guidance for contexts where accounting for dam retention would be important to avoid biased water quality estimates.

Finally, we extended prior implementations of this index by incorporating a broader suite of pollutants in the scenario analysis. Assuming the WQI we used is representative of the way people perceive water quality, we investigated bias in alternative specifications that omit pollutants completely and reweight the WQI, or hold them at baseline levels in the scenario analysis. We find that there is the potential for wide discrepancy in both baseline WQI and WQI change, depending on the specification of the index in the applied setting

run the risk of losing a significant signal in the estimates (Guswa et al. 2014). Therefore, the analysis resolution of marginal change maps needs to carefully weigh the two and often is best presented at the watershed scale, where most hydrological models are derived. of a coastal watershed system. When conducting scenario analysis with the IAM, holding pollutants at observed/estimated baseline levels generally fares better than omitting pollutants, as baseline conditions remain unbiased; however, all alternate specifications provide biased change estimates. Since the main retrospective water quality changes in Narragansett Bay were to nitrogen and phosphorus point-source loading and induced changes in dissolved oxygen and chlorophyll $a$, holding sediment and enterococcus steady produced little bias in WQI change estimates. While it would have been reasonable to leave them at their sample means, this does not hold generally, and relationships, both direct and indirect, between all drivers of change and pollutants in a given application must be established to gauge the potential for bias if insufficient data or effort precludes modeling all relevant pollutants.

There are a wide array of limitations and avenues for improvement for this IAM, most of which are common to the current state of hydrological or benefit transfer modeling. ${ }^{16}$ The foremost issue unique to this work is that large integrated models increase the number of potential sources of uncertainty, something we explore here in a very limited way in the modeling for each pollutant and do not attempt to compound throughout the model. The addition of four pollutants to the set typically used to model water quality scenarios relied on fairly limited or conflicting peer-reviewed evidence linking these additional pollutants either directly or indirectly to common management interventions. This was particularly the case with enterococcus modeling, where prior studies provide conflicting evidence that land use plays a role in observed concentrations, suggesting this might be highly context specific and/or the underlying processes are not well understood theoretically. This underscores the broader model uncertainty across all pollutants due to a lack of unifying theoretical models in hydrology (Clark et al. 2016; Mizukami et al. 2017). While model

\footnotetext{
${ }^{16}$ See Johnston and Rosenberger (2010) for a review of methodological and practical considerations for benefit transfer and Guswa et al. (2014) for a similar review of hydrology in the context of applied decision-making.
} 
uncertainty will be a longer-term issue in the respective subfields that comprise this IAM, a clearer understanding of parameter uncertainty would be a valuable next step for this model to increase confidence in our hydrological results, ${ }^{17}$ especially at scales smaller than the entire watershed, where WQI values are small in magnitude.

Modeled changes from most of the interventions in this case study produced small ( $\leq 5$ points) changes in water quality; this includes all simulated nonpoint-source interventions and even removing all dams in the watershed. However, the mean water quality change observed in the metadata for the benefit transfer function was 18.3 points $(\mathrm{SD}=$ 1.83). This exceeds the estimated change from recent wastewater treatment upgrades in this watershed that removed $42 \%$ and $30 \%$ of all nitrogen and phosphorus loading, respectively, into Narragansett Bay from 2001 to 2011. This raises concerns about the validity of extrapolating WTP measures out of sample to small changes in water quality and whether we have a good understanding of whether these values may systematically deviate from larger changes. Given that (1) small changes are the norm, not the exception, in this watershed and in most contemporary EPA regulations promulgated under the Clean Water Act (Newbold, Simpson, et al. 2018), (2) this sort of temperate coastal watershed with limited agricultural presence is common in the United States and adjacent to large population centers in the Mid-Atlantic, Northeast, and Northwest (Drummond and Loveland 2010), and (3) we observed significant stakeholder interest in outreach about the value of small-scale interventions like forest conservation and riparian buffers, a better understanding of how people value small water quality changes would have significant applied value.

While this analysis established that an inclusive IAM for water quality is possible, replicating such an effort elsewhere would require significant effort currently. In particular,

\footnotetext{
${ }^{17}$ With sufficient parameter variation, rank ordering could easily shift between conservation options in our marginal mapping exercise, which has been shown to have the potential to easily erode the efficiency of a conservation program (Johnson et al. 2012).
}

gathering and preprocessing data was challenging, and assessment of the rural-urban gradient in this watershed required significant effort to properly reflect wastewater treatment networks in the analysis. Incorporating dams into the analysis was facilitated by a recent study in the area that catalogued dams and estimated their nitrogen retention (Gold et al. 2016), and the bacterial analysis also relied on data that are not nationally available in the United States. The peer-reviewed science behind the bacteria and dam analyses could also use additional supporting research to confidently include them in a water quality IAM. Finally, estuarine applications of this IAM that extend beyond our case study to oceanographically mix pollutants into coastal waterways will face significant additional challenge, as estuarine mixing is context dependent and will likely require locally calibrated models.

Despite these challenges, this work greatly benefited from an expanding set of tools that helped automate portions of the IAM and took advantage of many data sources with national, and in some cases global, coverage. Continuing to expand data availability and tools to help facilitate workflows in this IAM, such as the work covered by Corona et al. (2020), can make these sorts of models more wieldy and extensible in new locations and contexts. More contributions toward establishing best practices for water quality IAMs, as we present here when considering how inclusive to be when including pollutants, will help identify scientific priorities while providing practical guidance for estimating water quality changes as these efforts continue.

\section{Acknowledgments}

The authors wish to thank Kelly Addy, Dana Bauer, Eli Fenichel, Mike Gerel, Art Gold, Perrine Hamel, Cindy Hannus, Rob Johnston, Dawn Kotowicz, Amber Neville, Sherry Poucher, Judith Swift, Jim Tobey, and the organizers and participants of the 2019 Social Cost of Water Pollution workshop at Cornell University for helpful comments, feedback, and assistance during this project. This project was supported by the URI Coastal Institute, National Oceanic and Atmospheric Administration award NA14OAR4320158, and 
assistance agreement SE 00A00252 awarded by the U.S. Environmental Protection Agency to Mass Audubon. Uchida acknowledges support from the National Science Foundation (\#OIA-1655221) and RI EPSCoR. The views expressed in this project are solely those of the authors. It has not been formally reviewed by the EPA or other funding agencies.

\section{References}

Addor, N., and L. A. Melsen. 2019. "Legacy, Rather Than Adequacy, Drives the Selection of Hydrological Models." Water Resources Research 55 (1): 378-90.

Allan, J. David. 2004. "Landscapes and Riverscapes: The Influence of Land Use on Stream Ecosystems." Annual Review of Ecology, Evolution, and Systematics 35 (1): 257-84.

Bateman, I. J., R. Brouwer, S. Ferrini, M. Schaafsma, D. N. Barton, A. Dubgaard, B. Hasler, S. Hime, I. Liekens, S. Navrud, et al. 2011. "Making Benefit Transfers Work: Deriving and Testing Principles for Value Transfers for Similar and Dissimilar Sites Using a Case Study of the Non-market Benefits of Water Quality Improvements across Europe.” Environmental and Resource Economics 50 (3): 365-87.

Bbalali, Saeed, Seyed Abbas Hoseini, Rasool Ghorbani, and Hamideh Kordi. 2013. "Relationships between Nutrients and Chlorophyll $a$ Concentration in the International Alma Gol Wetland, Iran." Journal of Aquaculture Research and Development 4 (3): 1000173.

Brauman, Kate A. 2015. "Hydrologic Ecosystem Services: Linking Ecohydrologic Processes to Human Well-being in Water Research and Watershed Management." Wiley Interdisciplinary Reviews: Water 2 (4): 345-58.

Brune, Gunnar M. 1953. "Trap Efficiency of Reservoirs." Transactions, American Geophysical Union 34 (3): 407-18.

Carson, Richard T., and Robert Cameron Mitchell. 1993. "The Value of Clean Water: The Public's Willingness to Pay for Boatable, Fishable, and Swimmable Quality Water." Water Resources Research 29 (7): 2445-54.

Clark, Martin P., Bettina Schaefli, Stanislaus J. Schymanski, Luis Samaniego, Charles H. Luce, Bethanna M. Jackson, Jim E. Freer, Jeffrey R. Arnold, R. Dan Moore, Erkan Istanbulluoglu, and Serena Ceola. 2016. "Improving the Theoretical Underpinnings of Process-Based Hydro- logic Models." Water Resources Research 52 (3): 2350-65.

Corona, Joel, Todd Doley, Charles Griffiths, Matthew Massey, Chris Moore, Stephen Muela, Brenda Rashleigh, William Wheeler, Stephen D. Whitlock, and Julie Hewitt. 2020. "An Integrated Assessment Model for Valuing Water Quality Changes in the United States." Land Economics 96 (4): 000-000.

Cude, Curtis G. 2001. "Oregon Water Quality Index: A Tool for Evaluating Water Quality Management Effectiveness." Journal of the American Water Resources Association 37 (1): 125-37.

Drummond, Mark A., and Thomas R. Loveland. 2010. "Land-Use Pressure and a Transition to Forest-Cover Loss in the Eastern United States." BioScience 60 (4): 286-98.

Dunnette, D. A. 1979. "A Geographically Variable Water Quality Index Used in Oregon.” Journal of the Water Pollution Control Federation 52 (1): 53-61.

EPA (U.S. Environmental Protection Agency). 2009. Environmental Impact and Benefits Assessment for Final Effluent Guidelines and Standards for the Construction and Development Category. EPA-821-R-09-012. Washington, DC: U.S. Environmental Protection Agency.

. 2010. Economic Analysis of Final Water Quality Standards for Nutrients for Lakes and Flowing Waters in Florida. Washington, DC: U.S. Environmental Protection Agency.

- 2015. Benefit and Cost Analysis for the Effluent Limitations Guidelines and Standards for the Steam Electric Power Generating Point Source Category. EPA-821-R-15-005. Washington, DC: U.S. Environmental Protection Agency.

Fant, Charles, Raghavan Srinivasan, Brent Boehlert, Lisa Rennels, Steven C. Chapra, Kenneth M. Strzepek, Joel Corona, Ashley Allen, and Jeremy Martinich. 2017. "Climate Change Impacts on US Water Quality Using Two Models: HAWQS and US Basins." Water 9 (2): 118.

Fisher, D. S., J. L. Steiner, D. M. Endale, J. A. Stuedemann, H. H. Schomberg, A. J. Franzluebbers, and S. R. Wilkinson. 2000. "The Relationship of Land Use Practices to Surface Water Quality in the Upper Oconee Watershed of Georgia." Forest Ecology and Management 128 (1-2): 39-48.

Freeman III, A. Myrick, Joseph A. Herriges, and Catherine L. Kling. 2014. The Measurement of 
Environmental and Resource Values: Theory and Methods, 3rd ed. New York: Routledge/ RFF Press.

Frenzel, Steven A., and Charles S. Couvillion. 2002. "Fecal Indicator Bacteria in Streams along a Gradient of Residential Development." Journal of the American Water Resources Association 38 (1): 265-73.

Gold, Arthur J., Kelly Addy, Alisa Morrison, and Marissa Simpson. 2016. "Will Dam Removal Increase Nitrogen Flux to Estuaries?" Water 8 (11): 522.

Guswa, Andrew J., Kate A. Brauman, Casey Brown, Perrine Hamel, Bonnie L. Keeler, and Susan Stratton Sayre. 2014. "Ecosystem Services: Challenges and Opportunities for Hydrologic Modeling to Support Decision Making." Water Resources Research 50 (5): 4535-44.

Hamel, Perrine, Rebecca Chaplin-Kramer, Sarah Sim, and Carina Mueller. 2015. "A New Approach to Modeling the Sediment Retention Service (InVEST 3.0): Case Study of the Cape Fear Catchment, North Carolina, USA." Science of the Total Environment 524-525: 166-77.

Hamel, Perrine, Kim Falinski, Richard Sharp, Daniel A. Auerbach, María Sanchez-Canales, and P. James Dennedy-Frank. 2017. "Sediment Delivery Modeling in Practice: Comparing the Effects of Watershed Characteristics and Data Resolution across Hydroclimatic Regions." Science of the Total Environment 580: 1381-88.

Heiskary, Steven, and Howard Markus. 2001. "Establishing Relationships among Nutrient Concentrations, Phytoplankton Abundance, and Biochemical Oxygen Demand in Minnesota, USA, Rivers." Lake and Reservoir Management 17 (4): 251-62.

Hoyer, Mark V., Thomas K. Frazer, Sky K. Notestein, and Daniel E. Canfield Jr. 2002. "Nutrient, Chlorophyll, and Water Clarity Relationships in Florida's Nearshore Coastal Waters with Comparisons to Freshwater Lakes." Canadian Journal of Fisheries and Aquatic Sciences 59 (6): 1024-31.

Johnson, Kris A., Brent J. Dalzell, Marie Donahue, Jesse Gourevitch, Dennis L. Johnson, Greg S. Karlovits, Bonnie Keeler, and Jason T. Smith. 2016. "Conservation Reserve Program (CRP) Lands Provide Ecosystem Service Benefits That Exceed Land Rental Payment Costs." Ecosystem Services 18: 175-85.

Johnson, Kris A., Stephen Polasky, Erik Nelson, and Derric Pennington. 2012. "Uncertainty in Ecosystem Services Valuation and Implications for Assessing Land Use Tradeoffs: An Agricultural Case Study in the Minnesota River Basin." Ecological Economics 79: 71-79.

Johnston, Robert J., and Dana Marie Bauer. 2019. "Using Meta-analysis for Large-Scale Ecosystem Service Valuation: Progress, Prospects and Challenges." Working paper. George Perkins Marsh Institute, Clark University, Worcester, MA.

Johnston, Robert J., Elena Y. Besedin, and Ryan Stapler. 2017. "Enhanced Geospatial Validity for Meta-analysis and Environmental Benefit Transfer: An Application to Water Quality Improvements." Environmental and Resource Economics 68 (2): 343-75.

Johnston, Robert J., and Randall S. Rosenberger. 2010. "Methods, Trends, and Controversies in Contemporary Benefit Transfer." Journal of Economic Surveys 24 (3): 479-510. https://doi. org/10.1111/j.1467-6419.2009.00592.x.

Johnston, Robert J., and Paul J. Thomassin. 2010. "Willingness to Pay for Water Quality Improvements in the United States and Canada: Considering Possibilities for International Meta-analysis and Benefit Transfer." Agricultural and Resource Economics Review 39 (1): 114-31.

Keeler, Bonnie L., Stephen Polasky, Kate A. Brauman, Kris A. Johnson, Jacques C. Finlay, Ann O'Neill, Kent Kovacs, and Brent Dalzell. 2012. "Linking Water Quality and Well-being for Improved Assessment and Valuation of Ecosystem Services." Proceedings of the National Academy of Sciences U S A 109 (45): 18619-24.

Keiser, David. 2018. "The Missing Benefits of Clean Water and the Role of Mismeasured Pollution." Economics Working Paper 18011. Ames: Department of Economics, Iowa State University.

Keiser, David A., Catherine L. Kling, and Joseph S. Shapiro. 2018. "The Low but Uncertain Measured Benefits of US Water Quality Policy." Proceedings of the National Academy of Sciences U S A 116 (12): 5262-69.

Keiser, David A., and Nicholas Z. Muller. 2017. "Air and Water: Integrated Assessment Models for Multiple Media." Annual Review of Resource Economics 9 (1): 165-84.

Kling, Catherine L., and Daniel J. Phaneuf. 2018. "How Are Scope and Adding Up Relevant for Benefits Transfer?" Environmental and Resource Economics 69 (3): 483-502.

Kling, Catherine L., Daniel J. Phaneuf, and Jinshua. Zhao. 2012. "From Exxon to BP: Has Some Number Become Better Than No Num- 
ber?" Journal of Economic Perspectives 26 (4): 3-26.

Leonard, Lorne, Alan M. MacEachren, and Kamesh Madduri. 2017. "Graph-Based Visual Analysis for Large-Scale Hydrological Modeling." Information Visualization 16 (3): 205-16.

Maavara, T., C.T. Parsons, C. Ridenour, S. Stojanovic, H.H. Dürr, H.R. Powley, and P.V. Cappellen. 2015. "Global Phosphorus Retention by River Damming." Proceedings of the National Academy of Sciences U S A 112 (51): 15603-8.

Meade, Robert H. 1982. "Sources, Sinks, and Storage of River Sediment in the Atlantic Drainage of the United States." Journal of Geology 90 (3): 235-52.

Meehan, Timothy D., Claudio Gratton, Erica Diehl, Natalie D. Hunt, Daniel F. Mooney, Stephen J. Ventura, Bradford L. Barham, and Randall D. Jackson. 2013. "Ecosystem-Service Tradeoffs Associated with Switching from Annual to Perennial Energy Crops in Riparian Zones of the US Midwest.” PLOS ONE 8 (11): e80093.

Mizukami, Naoki, Martyn P. Clark, Andrew J. Newman, Andrew W. Wood, Ethan D. Gutmann, Bart Nijssen, Oldrich Rakovec, and Luis Samaniego. 2017. "Towards Seamless Large-Domain Parameter Estimation for Hydrologic Models." Water Resources Research 53 (9): 8020-40.

NBEP (Narragansett Bay Estuary Program). 2017. The State of Narragansett Bay and Its Watershed. Technical report. Providence, RI: Narragansett Bay Estuary Program. Available at http:// nbep.org/01/wp-content/uploads/2017/03/ State-of-Narragansett-Bay-and-Its-Watershed-lower-resolution.pdf.

Nearing, Mark A., Garrett R. Foster, L. J. Lane, and S. C. Finkner. 1989. "A Process-Based Soil Erosion Model for USDA-Water Erosion Prediction Project Technology." Transactions of the ASAE 32 (5): 1587-1593.

Newbold, Stephen, R. David Simpson, D. Matthew Massey, Matthew T. Heberling, William Wheeler, Joel Corona, and Julie Hewitt. 2018. "Benefit Transfer Challenges: Perspectives from US Practitioners." Environmental and Resource Economics 69 (3): 467-81.

Newbold, Stephen, Patrick J. Walsh, D. Matthew Massey, and Julie Hewitt. 2018. "Using Structural Restrictions to Achieve Theoretical Consistency in Benefit Transfers." Environmental and Resource Economics 69 (3): 529-53.

Oczkowski, Autumn, Courtney Schmidt, Emily Santos, Kenneth Miller, Alana Hanson, Donald
Cobb, Jason Krumholz, Adam Pimenta, Leanna Heffner, Sandra Robinson, Joaquín Chaves, and Rick McKinney. 2018. "How the Distribution of Anthropogenic Nitrogen Has Changed in Narragansett Bay (RI, USA) Following Major Reductions in Nutrient Loads." Estuaries and Coasts 41 (8): 2260-76.

Olander, Lydia P., Robert J. Johnston, Heather Tallis, James Kagan, Lynn A. Maguire, Stephen Polasky, Dean Urban, James Boyd, Lisa Wainger, and Margaret Palmer. 2018. "Benefit Relevant Indicators: Ecosystem Services Measures That Link Ecological and Social Outcomes." Ecological Indicators 85: 1262-72.

Oleson, Kirsten L. L., Kim A. Falinski, Joey Lecky, Clara Rowe, Carrie V. Kappel, Kimberly A. Selkoe, and Crow White. 2017. "Upstream Solutions to Coral Reef Conservation: The Payoffs of Smart and Cooperative Decision-making." Journal of Environmental Management 191: 8-18.

Oviatt, Candace, Leslie Smith, Jason Krumholz, Catherine Coupland, Heather Stoffel, Aimee Keller, M. Connor McManus, and Laura Reed. 2017. "Managed Nutrient Reduction Impacts on Nutrient Concentrations, Water Clarity, Primary Production, and Hypoxia in a North Temperate Estuary." Estuarine, Coastal, and Shelf Science 199: 25-34.

Plummer, Mark L. 2009. "Assessing Benefit Transfer for the Valuation of Ecosystem Services." Frontiers in Ecology and the Environment 7 (1): $38-45$.

Plummer, Ryan, Rob de Loë, and Derek Armitage. 2012. "A Systematic Review of Water Vulnerability Assessment Tools." Water Resources Management 26 (15): 4327-46.

Polasky, Stephen, Catherine L. Kling, Simon A. Levin, Stephen R. Carpenter, Gretchen C. Daily, Paul R. Ehrlich, Geoffrey M. Heal, and Jane Lubchenco. 2019. "Role of Economics in Analyzing the Environment and Sustainable Development." Proceedings of the National Academy of Sciences U S A 116 (12): 5233-38.

Posner, Stephen M., Emily McKenzie, and Taylor H. Ricketts. 2016. "Policy Impacts of Ecosystem Services Knowledge." Proceedings of the National Academy of Sciences U S A 113 (7): 1760-65.

Prasad, M. Bala. Krishna, Wen Long, Xinsheng Zhang, Robert J. Wood, and Raghu Murtugudde. 2011. "Predicting Dissolved Oxygen in the Chesapeake Bay: Applications and Implications." Aquatic Sciences 73 (3): 437-51. 
Rabotyagov, Sergey S., Todd D. Campbell, Michael White, Jeffrey G. Arnold, Jay Atwood, M. Lee Norfleet, Catherine L. Kling, Philip W. Gassman, Adriana Valcu, Jeffrey Richardson, et al. 2014. "Cost-effective Targeting of Conservation Investments to reduce the Northern Gulf of Mexico Hypoxic Zone." Proceedings of the National Academy of Sciences U S A 111 (52): 18530-35.

Rai, Sushanth Vishwanath, and Mandla Rajashekhar. 2014. "Effect of pH, Salinity and Temperature on the Growth of Six Species of Marine Phytoplankton." Journal of Algal Biomass Utilization 5 (4): 55-59.

Redhead, John W., Linda May, Tom H. Oliver, Perrine Hamel, Richard Sharp, and James M. Bullock. 2018. "National Scale Evaluation of the InVEST Nutrient Retention Model in the United Kingdom." Science of the Total Environment 610-611: 666-77.

Renard, K. G., G. R. Foster, G. A. Weesies, D. K. McCool, and D. C. Yoder, coordinators. 1997. Predicting Soil Erosion by Water: A Guide to Conservation Planning with the Revised Universal Soil Loss Equation (RUSLE). Agriculture Handbook 703. Washington, DC: U.S. Department of Agriculture.

Renwick, W. H., S. V. Smith, J. D. Bartley, and R. W. Buddemeier. 2005. "The Role of Impoundments in the Sediment Budget of the Conterminous United States." Geomorphology 71 (1-2): 99-111.

Ricketts, Taylor H., and Eric Lonsdorf. 2013. "Mapping the Margin: Comparing Marginal Values of Tropical Forest Remnants for Pollination Services." Ecological Applications 23 (5): 1113-23.

Ries, Kernell G. 1990. Estimating Surface-Water Runoff to Narragansett Bay, Rhode Island and Massachusetts. Water-Resources Investigations Report 89-4164. Denver, CO: U.S. Geological Survey.

Rosenberger, Randall S., and John B. Loomis. 2000. "Using Meta-analysis for Benefit Transfer: In-Sample Convergent Validity Tests of an Outdoor Recreation Database." Water Resources Research 36 (4): 1097-107.

Roy, Samuel G., Emi Uchida, Simone P. de Souza, Ben Blachly, Emma Fox, Kevin Gardner, Arthur J. Gold, Jessica Jansujwicz, Sharon Klein, Bridie McGreavy, et al. 2018. "A Multiscale Approach to Balance Trade-offs among Dam Infrastructure, River Restoration, and Cost."
Proceedings of the National Academy of Sciences U S A 115 (47): 12069-74.

Ruckelshaus, Mary, Emily McKenzie, Heather Tallis, Anne Guerry, Gretchen Daily, Peter Kareiva, Stephen Polasky, Taylor Ricketts, Nirmal Bhagabati, Spencer A. Wood, and Joanna Bernhardt. 2015. "Notes from the Field: Lessons Learned from Using Ecosystem Service Approaches to Inform Real-World Decisions." Ecological Economics 115: 11-21.

Ryther, John H., and William M. Dunstan. 1971. "Nitrogen, Phosphorus, and Eutrophication in the Coastal Marine Environment." Science 171 (3975): 1008-13.

Seitzinger, Sybil P., Renée V. Styles, Elizabeth W. Boyer, Richard B. Alexander, Gilles Billen, Robert W. Howarth, Bernhard Mayer, and Nico van Breemen. 2002. "Nitrogen Retention in Rivers: Model Development and Application to Watersheds in the Northeastern USA." Biogeochemistry 57 (1): 199-237.

Sharp, Richard, Heather Tallis, Taylor Ricketts, Anne Guerry, Spencer A. Wood, Rebecca Chaplin-Kramer, Erik Jeremy Nelson, Driss Ennaanay, Stacie Wolny, Nasser Olwero, et al. 2014. InVEST User's Guide. Stanford, CA: The Natural Capital Project.

Sowah, Robert A., Mussie Y. Habteselassie, David E. Radcliffe, Ellen Bauske, and Mark Risse. 2017. "Isolating the Impact of Septic Systems on Fecal Pollution in Streams of Suburban Watersheds in Georgia, United States." Water Research 108: 330-38.

Sowah, R., H. Zhang, D. Radcliffe, E. Bauske, and M. Y. Habteselassie. 2014. "Evaluating the Influence of Septic Systems and Watershed Characteristics on Stream Faecal Pollution in Suburban Watersheds in Georgia, USA." Journal of Applied Microbiology 117 (5): 1500-12.

Swamee, Prabhata K., and Aditya Tyagi. 2000. "Describing Water Quality with Aggregate Index." Journal of Environmental Engineering 126 (5): 451-55.

Toft, J. E., J. L. Burke, M. P. Carey, C. K. Kim, M. Marsik, D. A. Sutherland, K. K. Arkema, A. D. Guerry, P. S. Levin, T. J. Minello, et al. 2013. "From Mountains to Sound: Modelling the Sensitivity of Dungeness Crab and Pacific Oyster to Land-Sea Interactions in Hood Canal, WA." ICES Journal of Marine Science 71 (3): 725-38.

Tong, Susanna T. Y., and Wenli Chen. 2002. "Modeling the Relationship between Land Use and 
Surface Water Quality." Journal of Environmental Management 66 (4): 377-93.

Van Houtven, George, John Powers, and Subhrendu K. Pattanayak. 2007. "Valuing Water Quality Improvements in the United States Using Meta-analysis: Is the Glass Half-Full or HalfEmpty for National Policy Analysis?" Resource and Energy Economics 29 (3): 206-28.

Vaughan, W. 1981. "The Water Quality Ladder.” In An Experiment in Determining Willingness to Pay for National Water Quality Improvements, Robert Cameron Mitchell and Richard T. Carson, appendix 2. Washington, DC: Resources for the Future.

Vitro, Kristen A., Todd K. BenDor, Tania V. Jordanova, and Brian Miles. 2017. "A Geospatial Analysis of Land Use and Stormwater Management on Fecal Coliform Contamination in
North Carolina Streams." Science of the Total Environment 603-4:709-27.

Walsh, Patrick, and William Wheeler. 2012. "Water Quality Index Aggregation and Cost Benefit Analysis." Working paper 12-05. Washington, DC: U.S. Environmental Protection Agency.

Walters, Sarah P., Anne L. Thebo, and Alexandria B. Boehm. 2011. "Impact of Urbanization and Agriculture on the Occurrence of Bacterial Pathogens and stx Genes in Coastal Waterbodies of Central California." Water Research 45 (4): 1752-62.

Yang, Xiankun, and X. X. Lu. 2014. "Estimate of Cumulative Sediment Trapping by Multiple Reservoirs in Large River Basins: An Example of the Yangtze River Basin." Geomorphology 227: 49-59. 